\title{
Comparison of three herbicides and combinations for weed management in citrus
}

\author{
Ben Faber ${ }^{1}$, Travis Bean ${ }^{2}$, Oleg Daugovish ${ }^{1}$, Jose De Soto $^{1} \&$ Anna Howell ${ }^{1}$ \\ SUMMARY
}

At a clay loam site near Santa Paula, California, was examined the weed control efficacy of two products with the active ingredient indaziflam, applied at two rates (Alion $200^{\circledR} \mathrm{SC}$ at $365 \mathrm{ml} \mathrm{ha}^{-1}$ and Alion ${ }^{\circledR} 500 \mathrm{SC}$ at $\left.146 \mathrm{ml} \mathrm{ha}^{-1}\right)$. These were applied alone and in combination with rimsulfuron $\left(\right.$ Matrix $^{\circledR}$ ) at $146 \mathrm{ml} \mathrm{ha}^{-1}$, which was also applied alone at $292 \mathrm{ml} \mathrm{ha}^{-1}$, for a total of five herbicide treatments plus an untreated control for fall and spring application timings (November 2015 and February 2016, respectively). Treatments were applied to clean row middles that had been previously treated with glyphosate and shallow cultivation. Weed control was evaluated at two, four, and six months after treatment. The most common weeds in the plots were species of Malva, Conyza, Convolvulus, Euphorbia and Chenopodium. For all species combined, both indaziflam products plus rimsulfuron, Alion $200^{\circledR} \mathrm{SC}$ alone, and Matrix ${ }^{\circledR}$ alone had lower weed densities than untreated control regardless of time since treatment.

Index terms: indaziflam, rimsulfuron, pre-emergence, post-emergence.

\section{Comparação de três herbicidas e combinações para manejo de plantas daninhas em citros}

\section{RESUMO}

Em uma localidade com solo argiloso próxima de Santa Paula, Califórnia, foi examinada a eficácia de controle de plantas daninhas de dois herbicidas com o ingrediente ativo indaziflam, aplicado em duas doses (Alion $200^{\circledR} \mathrm{SC}$ a $365 \mathrm{ml} \mathrm{ha}^{-1}$ e Alion ${ }^{\circledR} 500 \mathrm{SC}$ a $146 \mathrm{ml} \mathrm{ha}^{-1}$ ). Estes foram aplicados sozinhos e em combinação com rimsulfuron (Matrix ${ }^{\circledR}$ ) a $146 \mathrm{ml} \mathrm{ha}^{-1}$, que também foi aplicado sozinho em $292 \mathrm{ml} \mathrm{ha}^{-1}$, para um total de cinco tratamentos com herbicidas, além da testemunha (sem herbicida), com aplicações no outono e primavera (novembro 2015 e fevereiro de 2016, respectivamente). Os tratamentos foram aplicados para controlar toda a entrelinha do pomar que foi previamente tratada com glyphosate e cultivo superficial. Foi avaliado o controle de plantas daninhas aos dois, quatro e seis meses após o tratamento. As plantas daninhas mais comuns nas parcelas foram as espécies de Malva, Conyza, Convolvulus, Euforia e Chenopodium. Para todas as espécies, ambos os herbicidas com indaziflam mais rimsulfuron, Alion $200^{\circledR} \mathrm{SC}$ e Matrix ${ }^{\circledR}$ aplicados isoladamente apresentaram menor densidade de plantas daninhas do que a testemunha, independente do tempo após o tratamento.

Termos de indexação: indaziflam, rimsulfuron, pré-emergência, pós-emergência.

\footnotetext{
${ }^{1}$ University of California Cooperative Extension - UCCE, University of California, Ventura, CA, USA

${ }^{2}$ University of California, Riverside, CA, USA

Corresponding author: Ben Faber, University of California Cooperative Extension - UCCE, University of California, 669 County Square Drive, Ventura, CA 93003, USA. E-mail: bafaber@ucanr.edu
} 


\section{INTRODUCTION}

Weeds can impact cultural operations, tree growth, and yields by altering the spray pattern of low-volume irrigation systems, intercepting soil-applied chemicals (fertilizer and agricultural chemicals), reducing grove temperatures during freeze events, and interfering with pruning and harvest operations. The presence of weeds in a citrus grove can also affect insect populations. Weeds growing around tree trunks may also create a favorable environment for pathogens that infect the trunk and roots (Futch et al., 2016). Weed species compete with citrus trees in many ways and with varying intensities; management of more competitive weeds such as Conyza bonariensis (L.) Cronq. and C. canadensis (L.) Cronq., Sorghum halapense (L.) Pers., Paspalum dilatatum Poiret, and Ipomoea purpurea (L.) Roth should be prioritized. While some weeds (e.g., Tribulus terrestris L., Xanthium strumarium L., Urtica urens L., Cirsium vulgare (Savi) Ten., and Picris echioides L.) may have low competitive effects on citrus trees, they can hinder labor operations and may also rank high for active management.

Herbicides used in a citrus grove are generally divided into two groups: 1) soil-applied herbicides (pre-emergence) that should be applied to fairly clean soil surfaces prior to weed emergence, and 2) foliar-applied herbicides (post-emergence) that are applied after weeds have emerged (Futch et al., 2016).

Pre-emergence herbicides are generally applied two to three times per year to maintain effective concentration of herbicide in the upper soil profile $(0$ to $5 \mathrm{~cm}$ ) where most weed propagules reside. Herbicides applied too early will not provide adequate weed control due to herbicide leaching or degradation on the soil surface or within the soil profile. Pre-emergence herbicides must be incorporated (mainly by rainfall or irrigation) and are usually broadcast on the entire orchard floor since growers do not know where weeds will emerge and to reduce risk of frost damage. Growers using drip irrigation or micro-sprinkler irrigation have a difficulty adequately incorporating pre-emergence herbicides, so usually try to apply them prior to predicted rainfall (Rector et al., 2003). Soil type can influence herbicide selection and rate used. Many pre-emergence herbicides including oxyfluorfen, pendimethalin, oryzalin, trifluralin, and metolachlor can be used on sandy soils without injuring citrus trees (McCloskey \& Wright, 1998).

Post-emergence herbicides are used to control weeds that escape control by pre-emergence herbicides or mechanical cultivation. They can be systemic or contact in activity. Systemic herbicides are moved within the target plant, killing the foliage and root system of the treated plant. Contact herbicides are active only on those parts of the weeds the herbicide comes into contact with. Hence, adequate spray coverage of the weeds is more critical than with systemic materials. These herbicides are effective on small annual weeds and usually only suppress growth of perennials (Futch et al., 2016). It should be noted that the majority of organic herbicides are contact herbicides. Glyphosate is a widely used systemic post-emergence herbicides used in citrus due to its efficacy on many weed species and relatively low cost (Sharma \& Singh, 2007), though continuous use over time will likely lead to the development of resistant populations in some weed species. Amongst other weed species, Conyza canadensis and C. bonariensis have both been reported to be resistant to glyphosate in California citrus (Heap, 2005).

To help reduce likelihood of herbicide resistance development, herbicides should be rotated and/or mixed with different modes-of-action. New herbicides and rotations are needed to address the increasing occurrence of resistance among weeds in citrus orchards, and provide more effective and economic, season-long control while minimizing crop injury.

Rimsulfuron is a relatively new pre-post emergence herbicide registered for use in California citrus. It has both grass and broad-leaf weed activity. Indaziflam, also recently introduced to California citrus, has a pre-emergence activity against many common grasses and broadleaf weeds. These herbicides have different modes of action and both are different from glyphosate, thus could fit well into weed and herbicide resistance management programs. The objective of the study was to evaluate efficacy of indaziflam and rimsulfuron and their combinations on weed control in established citrus orchard.

\section{MATERIALS AND METHODS}

At a clay loam site near the Southern California coastal town of Santa Paula $\left(34.3542^{\circ} \mathrm{N}, 119.0593^{\circ} \mathrm{W}\right)$, the weed control efficacy of two products with the active ingredient indaziflam, applied at two rates (Alion $200^{\circledR} \mathrm{SC}$ at $365 \mathrm{ml} \mathrm{ha}^{-1}$ and Alion ${ }^{\circledR} 500 \mathrm{SC}$ at $146 \mathrm{ml} \mathrm{ha}^{-1}$, [both products manufactured by Bayer CropScience]) was evaluated. These were applied alone and in combination with rimsulfuron (Matrix ${ }^{\circledR}$, manufactured by DuPont) at $146 \mathrm{ml} \mathrm{ha}^{-1}$, which was also applied alone at $292 \mathrm{ml} \mathrm{ha}^{-1}$ (Table 1), 
for a total of five treatments plus an untreated control for each fall and spring application timings (November 2015 and February 2016, respectively). The experiment was designed as randomized complete block with five replications, in a 0.5 ha mixed citrus variety planting on a $6 \mathrm{~m} \times 7 \mathrm{~m}$ tree spacing. There were four trees per treatment plot. Treatments were applied to $6 \mathrm{~m} \times 7 \mathrm{~m}$ plots with $\mathrm{CO}_{2}$-pressurized backpack sprayer at spray volume $4701 \mathrm{ha}^{-1}$ to clean row middles that had been previously treated with glyphosate and shallow cultivation one month

Table 1. Product and active ingredient names and rates

\begin{tabular}{ccc}
\hline Product & Active ingredient (\%) & Product rate \\
\hline Alion $^{\circledR} 200 \mathrm{SC}$ & indaziflam (19.05\%) & $365 \mathrm{ml} \mathrm{ha}^{-1}$ \\
Alion $^{\circledR} 500 \mathrm{SC}$ & indaziflam (45.46\%) & $146 \mathrm{ml} \mathrm{ha}^{-1}$ \\
Matrix $^{\circledR}$ & rimsulfuron (25\%) & $365 \mathrm{ml} \mathrm{ha}^{-1}$ \\
Matrix $^{\circledR}$ & rimsulfuron (25\%) & $146 \mathrm{ml} \mathrm{ha}^{-1}$ \\
\hline
\end{tabular}

prior to trial treatments. Weed counts, by species, were made within whole plots at two, four, and six months after each application time.

Results were analyzed as repeated measures mixed model ANOVA (replicates as random effects) with season of application, treatment and months after treatment and their interactions as fixed effects. Means separations were calculated using Tukey's Honest Significant Difference $(P \leq 0.05)$.

\section{RESULTS AND DISCUSSION}

For all the weed species found in the trial, all the herbicide treatments were effective in controlling weeds compared to the untreated control regardless of the evaluation period (Figure 1). The most common weeds in

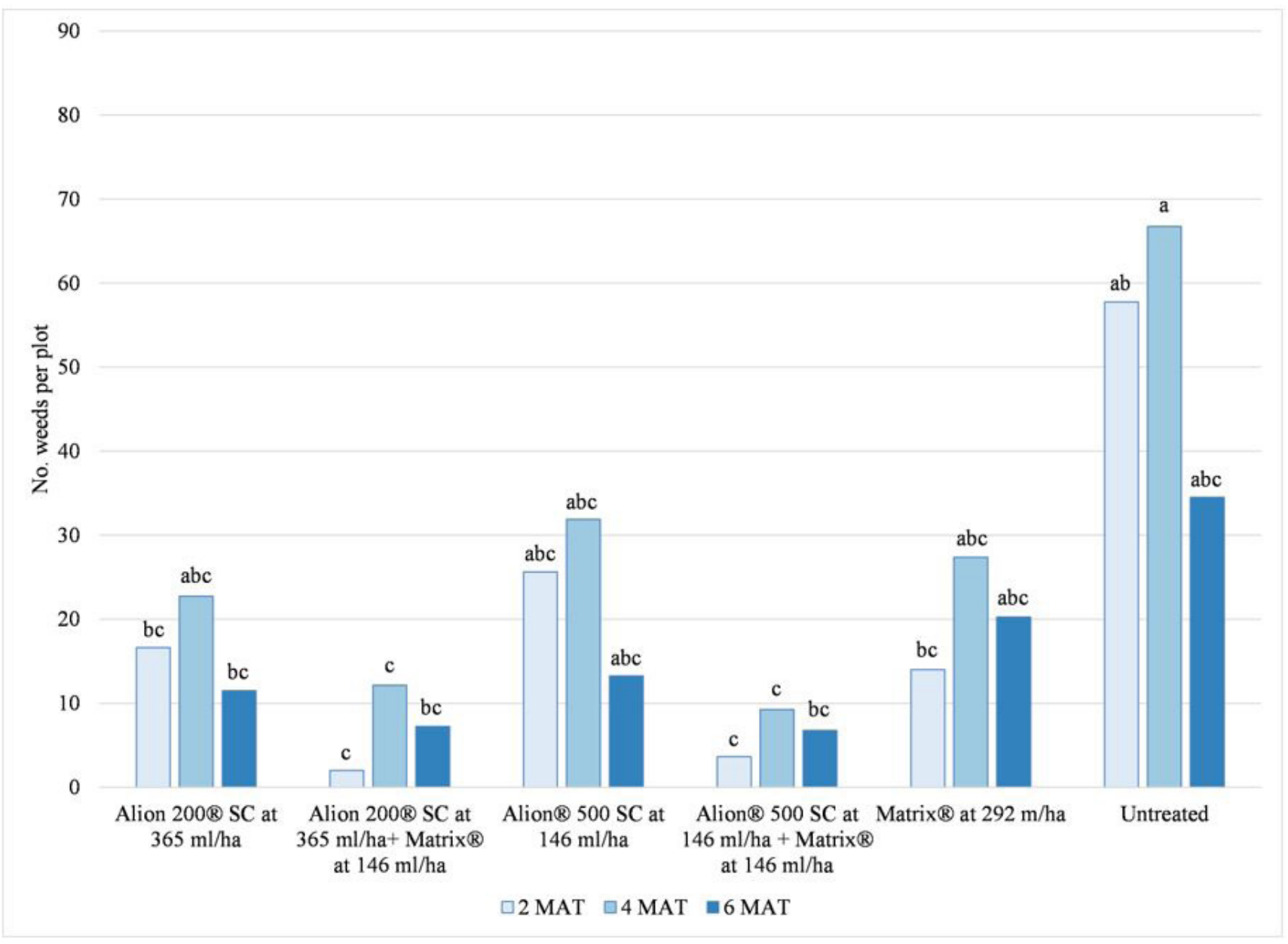

Figure 1. Weed density per plot at 2, 4, and 6 months after treatment (MAT), for both November and February applications combined. Tukey Honest Significant Difference letters are shown indicating means differences $(P \leq 0.05)$. Means followed by the same letter within each month do not differ. 
the plots were M. parviflora, C. canadensis, Convolvulus arvensis L., E. maculate L. and Chenopodium album L. For all species combined, both indaziflam products plus rimsulfuron, Alion ${ }^{\circledR} 200 \mathrm{SC}$ alone, and Matrix ${ }^{\circledR}$ alone had lower weed densities than untreated control regardless of time since treatment. Although Euphorbia was tolerant to this herbicide combination, we suspect that performance may be improved with the addition of a surfactant by reducing the surface tension for better incorporation into the soil (Futch \& Singh, 1999); U. urens, Portulaca oleracea $\mathrm{L}$., and $C$. arvensis were less affected than other species and possibly other materials need to be applied for their control, especially perennials like Convolulus (data not shown) (Westra et al., 1992).

November applications had lower weed densities than February applications, however drought conditions may have resulted in the observed differences in weed density by application timing, rimsulfuron requiring soil moisture activation (Renner \& Powell, 1998). The efficacy of all treatments continued for two and six months after treatment applications. Additional herbicide applications or integrated control might have provided longer-term control. Specifically, these herbicides provide good control of germinating weeds and may be paired with glyphosate that controls post-emerged weeds. This will ensure year-around control and minimize development of resistance due to rotation of modes of action in the program.

\section{REFERENCES}

Futch SH \& Singh M (1999) Herbicide mobility using soil leaching columns. Bulletin of Environmental Contamination and Toxicology 62(5): 520-529. PMid:10227830.

Futch SH, Sellers BA \& Singh M (2016) Florida pest management guide: weeds. Florida: Florida Cooperative
Extension Service. (Publication, HS-107). Available from: $<$ http://www.crec.ifas.ufl.edu/extension/pest/PDF/2016/ Weeds.pdf $>$. Accessed: 18 June 2017.

Heap I (2005) International survey of herbicide resistant weeds. Weed Science Society of America. Available from: $<$ www.weedscience.org $>$. Accessed: 8 June 2017.

McCloskey WB \& Wright GC (1998) Applying roundup to the base of lemon tree canopies: preliminary effects on leaves, flowers, fruitlets, and yield. In: Wright GC \& Kilby M (Eds). Citrus research report. Tucson: College of Agriculture, University of Arizona, p. 113. Available from: $<$ http://hdl.handle.net/10150/220570>. Accessed: 18 June 2017.

Rector RJWB, McCloskey GC, Wright GC \& Sumner C (2003) Citrus orchard floor management 2001-2003: comparison of a disk, "perfecta" cultivator, and weed sensing sprayer. In: Wright GC \& Kilby M (Eds). Citrus research report. Tucson: College of Agriculture, University of Arizona, p. 137. Available from: $<$ http:/hdl.handle. net/10150/198100>. Accessed: 18 June 2017.

Renner KA \& Powell GE (1998) Weed control in potato (Solanum tuberosum) with rimsulfuron and metribuzin. Weed Technology 12: 406-409.

Sharma SD \& Singh M (2007) Effect of timing and rates of application of glyphosate and carfentrazone herbicides and their mixtures on the control of some broad-leaf weeds. HortScience 42(5): 1221-1226.

Westra P, Chapman P, Stahlman PW, Miller SD \& Fay PK (1992) Field bindweed (convolvulus arvensis) with various herbicide combinations. Weed Technology 4: 949-955.

Received: May 09, 2017 Accepted: August 21, 2017 